- FINANSE I PRAWO FINANSOWE.

- Journal of Finance and Financial Law

https://doi.org/10.18778/2391-6478.2.22.06

\title{
SPOSOBY WYSTĘPOWANIA FAtSZYWYCH INFORMACJI NA RYNKU FINANSOWYM ORAZ FORMY OCHRONY PRZED NIMI
}

Aleksander Olejko

Uniwersytet Marii Curie-Skłodowskiej

\section{Streszczenie}

Niniejsza praca powstała poprzez zbadanie zagadnień zawartych w literaturze na temat fałszywych informacji. Ze szczególnym uwzględnieniem autor podszedł do kwestii fałszywych informacji na rynku finansowym. Jego celem jest przedstawienie czym one są, omówić jak występują na rynku finansowym oraz przedstawić działania jakie mogą pomóc w chronieniu się przed nimi.

Słowa kluczowe: fałszywe informacje, rynki finansowe, formy ochrony.

JEL Class: D11, D21, D53. 


\section{WPROWADZENIE}

W obecnych czasach jesteśmy świadkami coraz większego rozwoju na rynku finansowym. Ma to związek głównie z coraz bardziej innowacyjnymi technologiami, z którymi stykamy się na co dzień, jak i też z rozwojem zapotrzebowania i świadomości finansowej użytkowników tego rynku. Wywiera to większą presję na instytucjach, które świadczą takie usługi, by coraz bardziej dostosowywały się do wymogów rynku. Jednak z większym rozwojem rynku przychodzą też nowe zagrożenia. Jednym $\mathrm{z}$ największych zagrożeń jest zdecydowanie występowanie informacji fałszywych i mylących, które są szkodliwe dla wszystkich użytkowników rynku finansowego. Celem tego artykułu jest konkretne przestawienie tego, czym są fałszywe informacje, określenie jak występują na rynku finansowym oraz odpowiedź na pytanie, jak można się przed nimi uchronić. W celu dokonania tego autor zbadał dostępną na ten temat literaturę oraz przeanalizował zawarte w niej zagadnienia odnoszące się do tego tematu. Posłuży to do szerszego rozwinięcia postawionej hipotezy: „w dobie informacji trzeba być ostrożniejszym co do przekazywanych informacji”.

\section{CZYM SĄ FAŁSZYWE INFORMACJE I JAKIE SA ICH SKUTKI}

Jak wiadomo, informacje są do nas dostarczane z bardzo różnych źródeł i mają na celu przekazanie nam pewnego przekazu. Przekaz ten powinien być na tyle silny, by jego odbiorca mógł za nim podążyć w sposób określony przez nadawcę. Informacja przejawia pewną siłę, która oddziałuje na człowieka i jego mózg, w którym rodzą się wszelkie plany, zarówno w sprawie organizowania swojej codzienności, jak i podejmowania wyzwań odkrywczych i konstrukcyjnych, obejmujących zarówno problemy codzienności, jak i wymyślania oraz konstruowania nowych urządzeń, organizowania życia społecznego i wiele, wiele innych [Stefanowicz 2014: 83]. W związku z tym jak ogromną siłę ma dobrze przekazana informacja, nie możemy jej po prostu pasywnie odebrać, gdyż każda informacja zawrze $\mathrm{w}$ jego podświadomości pewien sposób postrzegania rzeczywistości [Stefanowicz 2014: 87].

Tak więc jako fałszywe informacje możemy określić te, które w sposób świadomy przez ich nadawcę mają przekonać odbiorcę, na skutek nieodpowiednich taktyk przekazu, do sformułowania opinii na dany temat, która będzie odbiegać od faktycznego obrazu rzeczywistości. Jako techniki prowadzące do tego wymienić można [Stefanowicz 2014: 88-89]:

- świadome podawanie nieprawdziwych informacji - $\mathrm{w}$ tym procesie nierzadko jest stosowany cyniczny zabieg, polegający na wplataniu pewnych znanych faktów w zupełnie inne treści, co ewidentnie wypacza wypowiadane zdania, 
- posługiwanie się mało znanymi lub wręcz nieznanymi terminami wykorzystywane w sytuacji przekonania o intelektualnym lenistwie odbiorcy informacji.

Przytoczone myśli są też niezwykle ważne teraz, w dobie cyfryzacji oraz coraz bardziej rozprzestrzeniającego się polegania społeczeństwa na Internecie. Przeciętny obywatel w ciągu dnie styka się z około pięcioma tysiącami komunikatów, nie wliczając $\mathrm{w}$ to tych internetowych, których jest zdecydowanie znacznie więcej [Hatalska 2008: 51]. Internet daje nam nieograniczony dostęp do masy informacji, które możemy w nim znaleźć. Jednak nie zawsze mogą być one prawidłowe, faktyczne lub potwierdzone. Występująca w ostatnich latach głośna dyskusja społeczna na temat fake newsów tylko to potwierdza.

Nie dziwi więc, że ludzie są coraz bardziej zaniepokojeni tym, jakie informacje odbierają, biorąc pod uwagę, że w różnych środowiskach, branżach a nawet działalnościach gospodarczych mogą być narażeni na oszustwo informacyjne. Na fałszywą informację możemy natknąć się z każdej strony i nie wiedząc, jak dobrze ją sprawdzić, możemy łatwo wpaść w pułapkę oszustwa.

Jednak nie wszyscy użytkownicy internetu są bardzo skrupulatni w odbiorze nadawanych do nich informacji. Wiążę się to z tym, że Internet, podobnie jak inne elektroniczne środki przekazu informacji, kształtuje społeczeństwo kierujące się powierzchownością ocen, gdyż ,poruszanie się w cyberprzestrzeni i wirtualnej rzeczywistości nie wymaga ani wysiłku intelektualnego, ani analitycznego myślenia, nie zmusza człowieka do cierpliwości ani do koncentracji umysłu, prowadząc często do uzależnienia go od służących mu urządzeń” [Morbitzer 2000: 185-194]. Przez to, że wielu odbiorców informacji w Internecie przyjmuje je bez dogłębnego zweryfikowania, coraz więcej osób jest narażonych na nieuczciwe potraktowanie informacjami nieuczciwymi. Ma to też miejsce na rynku instytucji finansowych, który to problem zostanie podjęty w drugiej części pracy.

\section{TECHNIKI WYKORZYSTYWANIA FAtSZYWYCH INFORMACJI NA RYNKU FINANSOWYM}

Istnieją różne techniki by wykorzystywać fałszywe informacje lub odpowiednio nimi manipulować. Niemniej każda z metod jest niebezpieczna, bo może pociągnąć za sobą szkodliwe konsekwencje dla każdego z użytkowników rynku finansowego, nieważne czy są to klienci, akcjonariusze czy inne podmioty. W tej części zostaną przytoczone jedne z najważniejszych metod przestępstw informacyjnych.

Pierwszą techniką jest manipulowanie informacją, co jest przykładem tak zwanej manipulacji instrumentem finansowym. Generalnie manipulacja instrumentami finansowymi ma na celu ukształtowanie danego obrazu rynku poprzez takie działania, jak składanie ofert, zawieranie transakcji lub skłanianie do tego innych uczest- 
ników rynku [Błachnio-Parzych 2011: 91]. Sama taktyka manipulowania informacjami polega na podawaniu do publicznej wiadomości informacji fałszywych o danej spółce, która jest notowana na giełdzie. Przykłady manipulowania informacjami to natomiast: rozpowszechnianie chronionych prawem informacji, przecieki informacji poufnych, zatajanie informacji o spółce lub jej działalności czy rozpowszechnianie mylących informacji [Wójcik 2008: 89-90].

W tym zjawisku menedżerowie mogą wykorzystać występowanie zjawiska asymetrii informacji między nimi a udziałowcami zewnętrznymi, by móc osiągnąć swoje prywatne korzyści finansowe w postaci otrzymania większego wynagrodzenia za osiągnięte wyniki. Inwestorzy, bazując na fałszywym, manipulowanym obrazie rynku, podejmują wówczas nieracjonalne decyzje, a zarządzający otrzymują bonusy [Piasecki 2015: 219-220].

Fałszywa informacja może być wpuszczona do publicznego obiegu oficjalnie, np. przez sfałszowaną sprawozdawczość, raport bieżący, okresowy, prospekt emisyjny, czy raport analityka, a także za pośrednictwem mediów lub w postaci pogłosek. Zazwyczaj mamy tu do czynienia z rozpowszechnianiem informacji pozytywnych, które mają na celu podwyższenie ceny. Rzadziej stosowany jest zabieg odwrotny - w celu obniżenia ceny lub wpłynięcia na cenę tak, by zamknąc zajętą na rynku pozycję [Wąsowski 2011: 34]. Najczęstszymi ofiarami manipulacji informacją są mali inwestorzy podążający za trendem i powodujący wzrost cen akcji poprzez ich kupowanie.

Innym przykładem zachowania nieuczciwego poprzez manipulację informacją jest zatajanie informacji, które mogą działać na niekorzyść danego przedsiębiorstwa, lecz są obrazem stanu faktycznego ich funkcjonowania. Przykładem tego może być przypadek, gdy przedsiębiorstwo ma problemy z płynnością finansową, lecz zarząd skrupulatnie ukrywa te informacje, działając tym samym na szkodę akcjonariuszy [www2, data dostępu: 31.03.2019]. Akcjonariusze mogą być w tym przypadku nieodpowiednio doinformowani o stanie przedsiębiorstwa, które nie chce, żeby akcjonariusze się z niego wycofywali. Często tego rodzaju sytuacje są rozwiązywane przez insider trading. Jednak jest to technika nielegalna, za którą grożą ogromne kary.

Te formy działania jednak odnoszą się do firm, które funkcjonują na giełdzie, mogą istnieć od dłuższego czasu, a nawet mieć duże poważanie i uznanie wśród ludzi. Jednak inaczej wygląda to na przypadku firm będących przedsięwzięciami piramidowymi lub parabankami. W przypadku piramid są to często przedsięwzięcia, które nie posiadają pozwolenia KNF na swoje działanie i promują się na różnych forach internetowych. Tego typu przedsiębiorstwa obiecują osobom, które wniosą odpowiedni wkład pieniężny zwrot danej części pieniędzy przy wprowadzaniu do systemu piramidowego następnych osób, a te powinny dalej wprowadzać nowe [Wójcik 2008: 284]. Oszustwo informacyjne polega tu głównie na tym, skąd ci na szczycie piramidy pozyskują pie- 
niądze, które są wypłacane osobom w strukturze. Tworzą oni obraz, że pozyskują je ze swoich inwestycji, które przeprowadzali na rynku. Jednak tak naprawdę są to po prostu pieniądze, które pozyskują od ludzi z dołu piramidy, które są w stanie wypłacać, gdyż tylko część z większości pieniędzy idzie do ludzi w dole [Pachucki 2012: 7-8].

Podobna rzecz tyczy się parabanków. W Polsce parabanki zaczęły pojawiać się na większą skalę na początku lat 90 -tych ubiegłego stulecia. Podmioty te używały różnych nazw m.in. „trusty inwestycyjne”, „konsorcja kapitałowe”, „holdingi finansowe”. Rejestrowane były jako spółki z o.o., a nabór klientów odbywał się często w sposób oficjalny i z dużym rozgłosem, jak chociażby poprzez prasę. Inwestorzy byli przyciągani przez wysokie oprocentowanie mające znacznie przewyższyć poziom inflacji [Kądziołka 2016: 8]. Podobnie jak w przypadku piramid, parabanki oszukują inwestorów co do tego, jak pozyskują środki mówiąc, że pochodzą one z inwestycji w aktywa.

Obydwie te formy oszustwa finansowego były w Polsce niezwykle popularne w latach dziewięćdziesiątych. Wielu obywateli przez nierozważne inwestycje straciło miliony złotych, których nigdy nie odzyskali. Informacje, które podawały tego rodzaju przedsiębiorstwa były bardzo zachęcające, gdyż obiecywały proste rozwiązania na zdobycie dużych ilości pieniędzy. Przyciągało to zwłaszcza nie uświadomionych mocno inwestorów i klientów. Gdy jednak przedsięwzięcia się załamywały ludzie zostawali z niczym, z wyjątkiem tych na szczycie. Nie są to jednak relikty przeszłości, gdyż nawet dzisiaj występują bardzo głośne afery na rynku inwestycyjnym, jak na przykład sprawa Amber Gold czy DasCoin.

\section{METODY OCHRONY PRZED OSZUSTWAMI INFORMACYJNYMI}

Po wyjaśnieniu czym jest fałszywa informacja oraz omówieniu technik podawania fałszywych informacji pora przejść do zagadnienia ochrony przed fałszywymi informacjami. A jest to, zdaniem autora, kwestia jedna z najważniejszych.

Jedną z pierwszych rzeczy, jakie można zrobić, jest zapoznanie się z danym przedsiębiorstwem lub instytucją w zbiorze danych Komisji Nadzoru Finansowego. KNF dokumentuje, które z przedsiębiorstw zostały uznane za szerzące fałszywe informacje na rynku i które zostały za to ukarane. Oczywiście, jeśli sami zdołamy wykryć takie nadużycie, także możemy to zgłosić do KNF, by mogła zbadać dany przypadek.

Ważną rzeczą jest też oczywiście własna edukacja finansowa. Od tego tak naprawdę trzeba zacząc swoją przygodę z finansami i bycie uczestnikiem rynku finansowego. $\mathrm{W}$ obecnych czasach prawie nieograniczonego dostępu do wiedzy 
na niezwykle wiele tematów jest to prostsze niż kiedykolwiek. Możemy brać specjalne kursy na uczelniach, w Internecie, odpowiednio przeszukiwać literaturę.

Zakładając, że dostaliśmy ofertę na udział w raczej podejrzanie wyglądającej inwestycji, naturalnie chcemy podjąć pewne kroki, by nie „wpakować się” w żadną piramidę. Można wtedy podjąć następujące czynności [www1, data dostępu: 31.03.2019]:

Inwestuj tylko w rzeczy, które rozumiesz.

Kiedy kupujesz sztabkę złota, dostajesz sztabkę złota, którą możesz wziąć do ręki i sprzedać. Jeśli ktoś sugeruje, że możesz zyskać na „,ertyfikatach na opcje od wierzytelności zabezpieczonych hedgingowo na złocie, ropie i pszenicy z gwarancjami Funduszu Dobrych Długów i rolowaniem obligacji” to lepiej daj sobie spokój.

\section{Dowiedz się, dlaczego oprocentowanie może być tak duże.}

Nie ma zysku bez ryzyka. Jeśli ktoś oferuje ponadprzeciętne oprocentowanie, zawsze pytaj o przyczyny. Może się okazać, że emitent jest mało wiarygodny, że papiery nie posiadają zabezpieczenia albo fundusze będą inwestowane w ryzykowne instrumenty finansowe. Wówczas musisz starannie przeanalizować cała sprawę, ważąc potencjalne zyski potencjalnymi stratami i własna awersją do ryzyka. Jeśli jednak ktoś daje Ci ponadprzeciętne zyski bez ryzyka, uciekaj jak najszybciej.

\section{Sprawdź z jakich działań fundusz ma czerpać zyski.}

Unikaj skomplikowanych certyfikatów i niejasnych deklaracji. Jeśli fundusz inwestuje w złoto, upewnij się, że jest to złoto fizyczne, a nie papiery wartościowe w jakimś stopniu oparte na złocie. Jeśli uważasz, że masz wystarczającą wiedzę, żeby wejść w taki biznes, patrz punkt 1 .

\section{Nigdy nie inwestuj w piramidę finansową.}

Może ci się wydawać, że jeśli wejdziesz odpowiednio wcześnie to wyjdziesz z pieniędzmi, ale to nieprawda. Jeśli założymy, że poziom 1 to założyciel, a żeby wypłacić zyski każdy uczestnik piramidy powinien pozyskać sześciu nowych klientów, to na poziomie 13, liczba uczestników przekroczy liczbę mieszkańców Ziemi.

Sprawdź, czy podmiot któremu powierzasz pieniądze ma zezwolenie Komisji Nadzoru Finansowego lub jej zagranicznego wiarygodnego odpowiednika.

Zapoznaj się z listą ostrzeżeń KNF, na której zawarte są podejrzane firmy. Jeśli nie masz czasu na skomplikowane analizy, inwestuj w proste instrumenty, które zostaną przypisane do twojego indywidualnego konta lub otrzymasz je fizycznie i charakteryzują się dużą płynnością: akcje, obligacje, kruszec w fizycznej postaci. 


\section{PODSUMOWANIE}

Artykuł przestawił, zgodnie z wyznaczonym celem, jakie są formy fałszywych informacji występujące na rynku finansowym oraz pokazał jak można się przed nimi chronić. Wiedza ta jest jedną $\mathrm{z}$ kluczowych $\mathrm{w}$ erze informacji do funkcjonowania nie tylko $\mathrm{w}$ świecie finansów, lecz też w ogólnie pojętej przestrzeni publicznej. Dogłębna selektywność co do przekazów informacyjnych, które są nadawane z przeróżnych źródeł, to klucz do podejmowania bezpiecznych decyzji w dzisiejszych czasach.

\section{BIBLIOGRAFIA}

Błachnio-Parzych A., 2011, Kryminalizacja manipulacji instrumentami finansowymi, Wolters Kluwer.

Hatalska N., 2008, Nie tylko wielka piątka, czyli ambient media i marketing szeptany jako alternatywne formy komunikacji, „Reklama i PR na rozdrożu?”, Henryk Mruk (red.), Poznań.

Kądziołka K., 2016, Wybrane przestępstwa na rynku kapitałowym.

Morbitzer J., 2000, Internet a kształcenie ku madrości, [w:] J. Morbitzer (red.), Materiały X jubileuszowego ogólnopolskiego sympozjum naukowego „Techniki komputerowe w przekazie edukacyjnym". Wyd. Naukowe Akademii Pedagogicznej, Kraków.

Pachucki M., 2012, Piramidy i inne oszustwa na rynku finansowy. Poradnik klienta uslug finansowych, Komisja Nadzoru Finansowego, Warszawa.

Piasecki M., 2015, Ksztaltowanie wyników finansowych a wielkość zaciaganego kapitatu obcego spótek notowanych na Giełdzie Papierów Wartościowych w Warszawie, „Finanse, Rynki Finansowe, Ubezpieczenia", nr 73.

Stefanowicz B., 2014, Siła informacji, „Zeszyty Naukowe Wydziału Informatycznych Technik Zarządzania Wyższej Szkoły Informatyki Stosowanej i Zarządzania: Współczesne Problemy Zarządzania", nr 1, Warszawa.

Wąsowski W., 2011, Manipulacje gietdowe: od fatszywych informacji do nadużyć i przestępstw, „Przegląd Corporate Governance”, nr 2(26).

Wójcik J. W., 2008, Oszustwa finansowe: zagadnienia kryminologiczne i kryminalistyczne; zagrożenia z cyberprzestrzeni, łańcuszki, piramidy, parabanki, oszustwa: bankowe, giełdowe, kredytowe, zaliczkowe-nigeryjskie, system argentyński, inne, Wydawnictwo JWW.

[www1] https://goldenmark.com/pl/mysaver/piramida-finansowa/ [dostęp: 31.03.2019].

[www2] https://www.forbes.pl/gielda/kuszace-pieniadze-czyli-insider-trading/w34hjx5 [dostęp: 31.03.2019]. 


\title{
THE EUROPEAN SYSTEM OF FINANCIAL SUPERVISION AS AN INSTITUTION PROVIDING CONSUMER PROTECTION
}

\begin{abstract}
This piece was created by examination of issues contained in literature on the subject of fake news. Author with specific consideration touched the issue of fake news on the financial market. The point of this piece is to explain what are they, discuss how they occur on the financial market and show actions that can help with being secured from them.
\end{abstract}

Keywords: financial supervision, consumer protection, Europe. 